\title{
Properties of Natural Waxes Used in Dentistry
}

\author{
R. G. CRAIG, J. D. EICK, ${ }^{*}$ and F. A. PEYTON \\ University of Michigan, School of Dentistry, Ann Arbor, Michigan
}

Waxes used in dentistry are combinations of two or more natural waxes plus small amounts of additives, such as oils, natural resins, synthetic waxes, and coloring agents. The ultimate goal of the combination of waxes and additives is to produce dental waxes that possess a set of given physical properties over a specified range of temperature. Although considerable effort has been expended to determine the physical properties desired in dental wax ${ }^{1-3}$ and the properties of dental waxes during their manipulation, ${ }^{4-10}$ little information is available on the properties of the natural waxes ${ }^{11-16}$ used as components to produce dental waxes. Such studies have been confined to meltingpoint curves of binary and ternary mixtures; $;^{11-13}$ the effect of composition on the specific gravity; ${ }^{14}$ and the general composition of waxes, their melting points, and the effect of composition on the melting point. ${ }^{15-16}$

The purpose of this investigation, therefore, was to categorize the ingredient waxes used in dental waxes by means of physical tests. The flow qualities, melting range, setting range, and linear thermal expansion of mineral, plant, insect, and inlay waxes were measured in this study.

\section{Materials and Methods}

SELECTION of WAXEs.-The waxes investigated, together with their general categories and sources, are listed in Table 1. Paraffin waxes are of mineral origin from high boiling fractions of petroleum and are mixtures of chiefly straight-chain-saturated hydrocarbons which crystallize in plates or needles. Litene and barnsdahl are micro-

Read in part at the 41 st General Meeting of the IADR, Pittsburgh, Pa., March, 1963.

This investigation was supported in whole by USPHS Research Grant DE-01234 from the National Institute for Dental Research, National Institutes of Health, Bethesda, Md.

Received for publication July 20, 1964.

* Present address: Research Division, National Bureau of Standards, Washington, D.C. crystalline waxes similar to paraffin but obtained from heavier oil fractions. They are to a large extent composed of branched hydrocarbons, crystallize in small plates, and are tougher and more flexible than paraffin waxes. Ceresin is a term that describes waxes from distillates from natural mineral, petroleum, or lignite refining. They contain straight and branched hydrocarbon chains of higher molecular weights and are

TABLE, 1

Classification AND SOURCES OF WAXES INVESTIGATED

\begin{tabular}{|c|c|c|}
\hline Wax & Category & Source \\
\hline Paraffin .......... & Mineral & Petroleum \\
\hline Litene... & Mineral & $\left\{\begin{array}{l}\text { Petroleum } \\
\text { Microcrystalline }\end{array}\right.$ \\
\hline Barnsdahl. . & Mineral & Petroleum \\
\hline Ceresin.... & Mineral & Petroleum \\
\hline Montan. . & Mineral & Lignite \\
\hline Carnauba.. & Plant & Palm Tree \\
\hline Candelilla. . & Plant & $\begin{array}{l}\text { Wild succulent } \\
\text { plant }\end{array}$ \\
\hline Ouricury. & Plant & Palm tree \\
\hline Japan wax. . & Plant & $\begin{array}{l}\text { Berries of the } \\
\text { Sumac tree }\end{array}$ \\
\hline Beeswax (yellow) . . & Insect & Bees \\
\hline Beeswax (bleached). & Insect & Bees \\
\hline Kerr hard wax (blue). & Inlay & $\begin{array}{l}\text { Kerr Mfg. Com } \\
\text { pany }\end{array}$ \\
\hline $\begin{array}{l}\text { Kerr regular wax } \\
\text { (blue) } \ldots \ldots \ldots \ldots\end{array}$ & Inlay & $\begin{array}{l}\text { Kerr Mfg. Com } \\
\text { pany }\end{array}$ \\
\hline
\end{tabular}

harder than other hydrocarbon waxes. Montan waxes are obtained from various lignites, but unlike the other mineral waxes they are mixtures of long-chain esters accompanied by high molecular weight alcohols, acids, and resins. As a result, montan wax is hard and brittle.

Carnauba and ouricury waxes are composed of a mixture of straight-chain esters, alcohols, acids, and hydrocarbons. They are characterized by high hardness, brittleness, 
and high melting points. Candelilla wax, although a plant wax, contains $40-60$ per cent paraffin hydrocarbon accompanied by esters, alcohols, and acids. Japan wax is primarily a fat containing glycerides of palmitic, stearic, and other higher molecular weight acids.

Beeswax is an insect wax which is a complex mixture of esters, consisting mainly of myricyl palmitate plus saturated and unsaturated hydrocarbons and organic acids. It is supplied in a number of grades, the bleached type being of higher purity.

The commercial inlay wax is a mixture of waxes with a probable composition of 70 per cent mineral wax, 25 per cent plant wax, and 5 per cent beeswax.

The selection of waxes, therefore, includes a wide range of sources, composition, and properties. The properties of these waxes will control to a great extent the combinations used for various applications in dentistry.

Melting and Setting RANGes.-The melting range of four samples of each wax was tested using the closed-capillary-tube method as described by Warth. ${ }^{16}$ The setting range was determined from a plot of the temperature versus the time curve. A 10ounce glass jar of wax was melted in an electric oven and maintained for 15 minutes at a temperature about $20^{\circ} \mathrm{C}$. above its solidification point. The jar of molten wax was then placed in the center of a container 3 inches high and 3.5 inches in diameter, and asbestos insulation was packed around it. A warm thermometer, having a range between $-1^{\circ}$ and $101^{\circ} \mathrm{C}$. with $0.1^{\circ} \mathrm{C}$. subdivisions, was placed in the center of the wax, and the top of the container was sealed with a large cork. The amount of time between each $0.5^{\circ} \mathrm{C}$. temperature drop within a range $20^{\circ}$ above and $20^{\circ}$ below the setting range was recorded. Four samples of each wax were tested.

FLOW.-Specimens were prepared and tested in accordance with the American Dental Association Specification No. 4 for dental inlay casting wax. ${ }^{17}$ Flow tests were performed over a large temperature range, so that the flow properties could be determined accurately. An automatic micrometer flow tester* was used, and the amount of

*B. C. Ames Company, Waltham, Mass. flow each minute was recorded during the 10 -minute testing period.

THERMAL EXPANSION.-A porcelain crucible of wax was heated in an oven and maintained for approximately 15 minutes at $20^{\circ} \mathrm{C}$. above its melting range. The molten wax was poured into a brass mold consisting of a split cylinder $200 \mathrm{~mm}$. long and $12 \mathrm{~mm}$. in diameter, which had been lubricated with a high-melting-point silicone grease and preheated to approximately $10^{\circ} \mathrm{C}$. below the solidification point of the wax. As the wax cooled and shrinkage occurred, liquid wax was added. The wax was allowed to solidify without the application of pressure. The mold was allowed to cool in the atmosphere to room temperature and the wax specimen removed. Small metal pins having cross marks which served as reference points were imbedded in its surface near each end.

Three weights were attached to the specimen by means of string. The wax specimen was placed in a controlled-temperature water bath, so that the length of each string allowed it to float just below the surface of the water. The specimen was annealed for 24 hours at approximately $37^{\circ} \mathrm{C}$. A higher annealing temperature was used with the high melting waxes, and a lower temperature was utilized with the low melting waxes. The water bath was cooled to room temperature and the wax specimen allowed to come to equilibrium. The temperature of the bath was raised slowly, and the linear expansion was measured with two micrometer microscopes at approximately $1.5^{\circ} \mathrm{C}$. intervals between $20^{\circ}$ and $52^{\circ} \mathrm{C}$.

Four original samples of each wax were made. Each specimen was tested and then retested at least once. There was a total of eight individual tests run on each wax.

\section{Results}

SETTING AND MELTing RANGES.--The setting ranges of the mineral and insect waxes are listed in Table 2 . The paraffin wax used in this investigation exhibited a setting range between $51.5^{\circ}$ to $53.0^{\circ} \mathrm{C}$. This was the lowest setting range among the mineral waxes; barnsdahl had the highest setting range, $85.0^{\circ}-87.0^{\circ} \mathrm{C}$. Four of the five mineral waxes exhibited a range of $2^{\circ}$ or $3^{\circ} \mathrm{C}$. while solidifying. Ceresin was the exception, with a setting range between $52.0^{\circ}$ and $73.0^{\circ} \mathrm{C}$. 
TABLE 2

Setting Range and Flow Properties of Mineral, Insect, Plant, and Inlay Waxes

\begin{tabular}{|c|c|c|c|c|c|c|}
\hline \multirow[b]{2}{*}{ WAX } & \multirow[b]{2}{*}{$\begin{array}{l}\text { SETTING RANGE } \\
{ }^{\circ} \mathrm{C} \text {. }\end{array}$} & \multicolumn{3}{|c|}{ TEMPERATURE* } & \multirow{2}{*}{$\begin{array}{l}\text { TEMPPERA- } \\
\text { TURE } \\
\text { RANGE } \uparrow \\
{ }^{\circ} \mathrm{C}\end{array}$} & \multirow{2}{*}{$\begin{array}{l}\text { Setting Tempera- } \\
\text { TURE-Temperature } \\
\text { AT } 50 \text { Per CENT FLOW } \\
\text { 'C. }\end{array}$} \\
\hline & & $\begin{array}{l}1 \text { Per } \\
\text { Cent }\end{array}$ & $\begin{array}{c}50 \mathrm{Per} \\
\text { Cent }\end{array}$ & $\begin{array}{r}70 \text { Per } \\
\text { Cent }\end{array}$ & & \\
\hline \multicolumn{7}{|c|}{ Mineral Waxes } \\
\hline 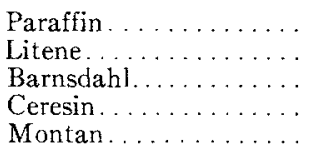 & $\begin{array}{l}51.5-53.0 \\
70.0-72.0 \\
85.0-87.0 \\
52.0-73.0 \\
78.5-80.5\end{array}$ & $\begin{array}{l}26.0 \\
42.0 \\
47.0 \\
30.0 \\
65.0\end{array}$ & $\begin{array}{l}31.5 \\
53.4 \\
58.0 \\
32.6 \\
71.1\end{array}$ & $\begin{array}{l}33.0 \\
55.2 \\
61.7 \\
33.0 \\
74.6\end{array}$ & $\begin{array}{r}7.0 \\
13.2 \\
14.7 \\
3.0 \\
9.4\end{array}$ & $\begin{array}{r}20.8 \\
17.6 \\
28.0 \\
20.4 \\
8.4\end{array}$ \\
\hline \multicolumn{7}{|c|}{ Insect Waxes } \\
\hline $\begin{array}{l}\text { Beeswax (yellow) ...... } \\
\text { Beeswax (bleached) .... }\end{array}$ & $\begin{array}{l}61.0-63.0 \\
61.0-63.0\end{array}$ & $\begin{array}{l}32.0 \\
39.2\end{array}$ & $\begin{array}{l}38.6 \\
41.8\end{array}$ & $\begin{array}{l}39.6 \\
42.8\end{array}$ & $\begin{array}{l}7.6 \\
3.6\end{array}$ & $\begin{array}{l}23.4 \\
20.2\end{array}$ \\
\hline \multicolumn{7}{|c|}{ Plant Waxes } \\
\hline $\begin{array}{l}\text { Carnauba............ } \\
\text { Candelilla........... } \\
\text { Ouricury .......... } \\
\text { Japan wax ......... }\end{array}$ & $\begin{array}{l}80.0-82.0 \\
63.0-66.0 \\
70.5-72.5 \\
41.5-44.0\end{array}$ & $\begin{array}{l}75.0 \\
56.0 \\
66.0 \\
39.5\end{array}$ & $\begin{array}{l}77.0 \\
59.5 \\
72.6 \\
42.5\end{array}$ & $\begin{array}{l}77.6 \\
60.0 \\
74.0 \\
43.5\end{array}$ & $\begin{array}{l}2.6 \\
4.0 \\
8.0 \\
4.0\end{array}$ & $\begin{array}{r}4.0 \\
5.0 \\
1.0\end{array}$ \\
\hline \multicolumn{7}{|c|}{ Inlay Waxes } \\
\hline Kerr hard wax (blue)... & $\begin{array}{l}57.0-59.5 \\
64.0-66.0\end{array}$ & 37.5 & 42.2 & 43.8 & 6.3 & 22.8 \\
\hline Kerr regular wax (blue). & $\begin{array}{l}55.0-57.5 \\
67.5-68.5\end{array}$ & 35.0 & 40.6 & 42.2 & 7.2 & $\begin{array}{l}27.4 \\
15.6\end{array}$ \\
\hline
\end{tabular}

* ${ }^{c}$ C. at which 1,50 , and 70 per cent flow occurs.

t Between 1 to 70 per cent flow.

Both yellow and bleached beeswax had a setting range between $61.0^{\circ}$ and $63.0^{\circ} \mathrm{C}$.

Temperature versus time curves for paraffin and yellow beeswax are shown in Figure 1. The solid lines represent cooling curves, and the dotted lines represent a plot of temperature versus the time between each $0.5^{\circ} \mathrm{C}$. reading. From these differential plots, it can be observed that the rate of temperature change for beeswax during solidification is much greater than that for paraffin during solidification.

The setting ranges of the plant and inlay waxes also are listed in Table 2 . Among the plant waxes, carnauba had the highest setting range $-80.0^{\circ}-82.0^{\circ} \mathrm{C}$ - - and Japan wax had the lowest $-41.5^{\circ}-44.0^{\circ} \mathrm{C}$. All the plant waxes solidified over a $2^{\circ}-4^{\circ} \mathrm{C}$. range. Japan wax was the only wax investigated that exhibited a temperature rise during solidification, as can be seen from the cooling curve plotted in Figure 2. Both inlay waxes exhibited two transition ranges (see Fig. 2); for example, Kerr's hard wax showed one range between $64.0^{\circ}$ and $66.0^{\circ} \mathrm{C}$. and another range between $57.0^{\circ}$ and $59.5^{\circ} \mathrm{C}$.

The melting-range determinations for all the waxes agreed reasonably with the setting-range values. The melting ranges, however, tended to be higher and gave broader ranges than the setting-range values. This was particularly true for the plant waxes.

FLow.-The temperature at which 1, 50, and 70 per cent flow occurred in 10 minutes, the temperature range between 1-70 per cent, and the setting temperature minus the temperature at 50 per cent flow for the mineral and insect waxes also are listed in Table 2. Paraffin flowed 50 per cent at $31.5^{\circ} \mathrm{C}$., whereas montan flowed 50 per cent at $71.1^{\circ} \mathrm{C}$. The temperature increase between 1 and 70 per cent flow was between 7 and $14.7^{\circ} \mathrm{C}$. for four of the five mineral waxes, although only a $3^{\circ} \mathrm{C}$. temperature rise was necessary for ceresin. The difference between the setting temperature of the wax and the temperature at which 50 per cent flow occurred was approximately $20^{\circ} \mathrm{C}$. for 
four of the mineral waxes. Montan wax, however, did not flow 50 per cent until $8^{\circ} \mathrm{C}$. below its setting range. A temperature of $38.6^{\circ} \mathrm{C}$. was necessary before yellow beeswax would flow 50 per cent, whereas a temperature of $41.8^{\circ} \mathrm{C}$. was necessary for bleached beeswax. The temperature increase between 1 and 70 per cent flow was approximately $4^{\circ} \mathrm{C}$. for bleached beeswax and $8^{\circ} \mathrm{C}$. for yellow beeswax. Both yellow and bleached beeswax flowed 50 per cent $20^{\circ} \mathrm{C}$. below their setting ranges.

The flow properties for the plant and inlay waxes are likewise described in Table 2. Temperatures between $42.5^{\circ}$ and $77.0^{\circ} \mathrm{C}$. were required to produce 50 per cent flow while testing the four plant waxes. All the plant waxes required little temperature rise between 1 and 70 per cent flow; for example, it was necessary to raise the temperature only $2.6^{\circ} \mathrm{C}$. for carnauba wax, and the largest temperature rise was $8.0^{\circ} \mathrm{C}$., exhibited by ouricury wax. The plant waxes did not flow extensively until they approached their setting range, and at this point they appeared to fracture rather than flow into a smooth circular disk. A temperature $5^{\circ}$ and $1^{\circ} \mathrm{C}$. below the setting range of candelilla and Japan wax, respectively, was necessary to produce 50 per cent flow.

Kerr's hard inlay wax flowed 50 per cent at $42.2^{\circ} \mathrm{C}$., and Kerr's regular wax flowed this amount at $40.6^{\circ} \mathrm{C}$. Both waxes exhibited approximately a $7.0^{\circ} \mathrm{C}$. temperature increase between 1 and 70 per cent flow. Also, both waxes flowed 50 per cent about $20^{\circ} \mathrm{C}$. below their setting ranges.

The per cent flow at 10 minutes versus temperature for the representative waxesparaffin, yellow beeswax, carnauba, and Kerr's hard inlay wax-is plotted in Figure 3. Both Kerr's hard inlay wax and beeswax exhibited their flow properties near mouth temperature. Paraffin flowed over a wide range of temperatures, which is shown by the gradual sloping flow curve. Carnauba did not flow until it reached a very high temperature close to its setting range, and the sharp sloping curve illustrates that this wax flowed over a small temperature range.

The per cent flow was determined at intervals of 1 minute during the flow tests. Figure 4 contains a plot of per cent flow versus time for Kerr's hard inlay wax at $40^{\circ}$, $42^{\circ}, 43^{\circ}$, and $45^{\circ} \mathrm{C}$. At $40^{\circ} \mathrm{C}$., the amount of flow in relation to time was linear. At $42^{\circ} \mathrm{C}$., the rate of flow was relatively small for the first 3 minutes, the rate then increased between 3 and 8 minutes, and finally the rate decreased between 8 and 10 minutes. Most of the flow took place within 6 minutes at $43^{\circ} \mathrm{C}$., and the major portion of the flow occurred within the first 3 minutes at $45^{\circ} \mathrm{C}$.

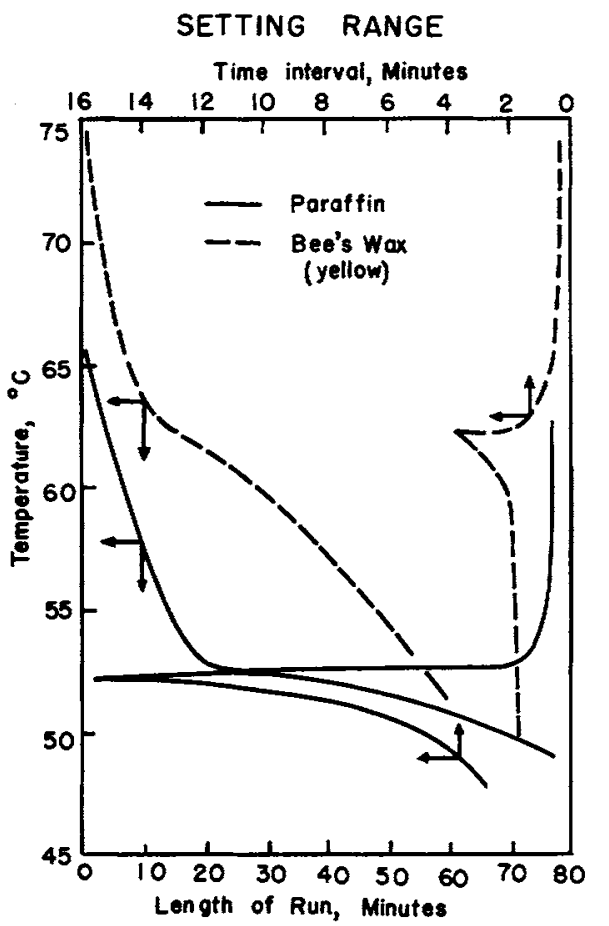

FIG. 1.- Setting-range tests of paraffin and yellow beeswax.

LINEAR THERMAL EXPANSION:- The coefficient of linear thermal expansion and the temperature ranges for all the waxes are listed in Table 3. Carnauba possessed the smallest coefficient-15o $\pm 10 \times 10^{-6} /{ }^{\circ} \mathrm{C}$. -of all the waxes and was the only wax which exhibited a linear expansion between $22^{\circ}$ and $52^{\circ} \mathrm{C}$. All the other waxes had at least two rates of expansion over this temperature range. Ouricury had a thermal coefficient of $186 \pm 14 \times 10^{-6} /{ }^{\circ} \mathrm{C}$. between $22^{\circ}$ and $43.0^{\circ} \mathrm{C}$. and a coefficient of $307 \pm$ $29 \times 10^{-6}{ }^{\circ} \mathrm{C}$. between $43.0^{\circ}$ and $52^{\circ} \mathrm{C}$. Kerr's hard inlay wax had three rates of expansion between $22^{\circ}$ and $50^{\circ} \mathrm{C}$., while 
ceresin and Kerr's regular inlay wax showed four rates of expansion over this temperature range.

The mineral waxes generally expanded

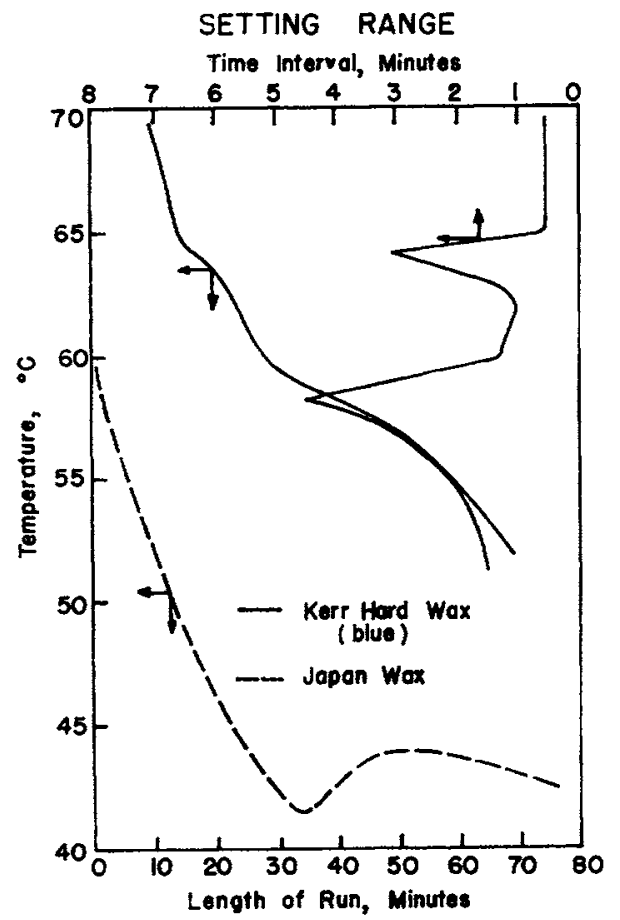

FIG. 2.- Setting-range test of Kerr hard wax and Japan wax. the greatest amount. Paraffin had the highest coefficient of thermal expansion of any wax tested, which was $1,631 \pm 237 \times$ $10^{-6} /{ }^{\circ} \mathrm{C}$. between $27.8^{\circ}$ and $34.0^{\circ} \mathrm{C}$. Litene, a mineral wax, had higher coefficients of thermal expansion between $22^{\circ}$ and $52^{\circ} \mathrm{C}$. than did ouricury, a plant wax, even though both waxes solidified over the same temperature range. Barnsdahl, another mineral wax which solidified $5^{\circ} \mathrm{C}$. higher than did carnauba, expanded more than carnauba over the same temperature range. Among the insect waxes, yellow beeswax expanded more than bleached beeswax over a temperature range between $22^{\circ}$ and $52^{\circ} \mathrm{C}$. Kerr's hard inlay wax expanded less than Kerr's regular inlay wax. It is interesting to note that Kerr's hard inlay wax showed an increase in the rate of expansion at $37.5^{\circ} \mathrm{C}$., or mouth temperature, and a decreased rate of expansion at $45.0^{\circ} \mathrm{C}$. Kerr's regular inlay wax, however, had an increase in the rate of thermal expansion at $32.7^{\circ} \mathrm{C}$., a decrease in rate of expansion at $40.9^{\circ} \mathrm{C}$., and an increase again at $46.9^{\circ} \mathrm{C}$. The linear coefficient of thermal expansion for the mineral, plant, and insect waxes increased as the temperature ranges approached the solidification ranges of the waxes.

The per cent linear expansion versus temperature for paraffin, carnauba, yellow beeswax, and Kerr's hard inlay wax is plotted in Figure 5. It can be seen that the rate of ex-

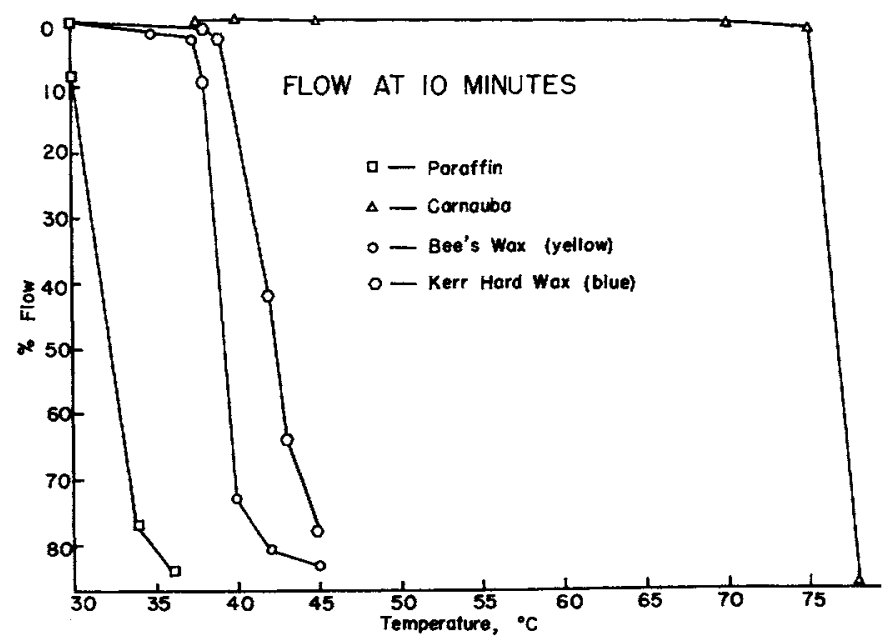

Fig. 3.-Flow at 10 minutes at various temperatures for paraffin, carnauba, yellow bees, and Kerr hard waxes. 
TABLE 3

COEFFicient of Thermal EXPANSION OF Mineral, INSECT, PLANT, AND INLAY WAXES

\begin{tabular}{|c|c|c|}
\hline Wax & $\begin{array}{l}\text { Temperature Range } \\
\left({ }^{\circ} \mathrm{C} .\right)\end{array}$ & $\begin{array}{c}\text { Coefficient of } \\
\text { Thermal Expansion } \\
\times 10^{-6}\end{array}$ \\
\hline \multicolumn{3}{|c|}{ Mineral } \\
\hline Paraffin . . . . . . . . . & $\begin{array}{l}20.0 \quad-27.8^{*} \pm 0.2 \dagger \\
27.8 \pm 0.2-34.0\end{array}$ & $\begin{array}{l}307^{*} \pm 20 \dagger \\
1,631 \pm 237\end{array}$ \\
\hline Litene. . . . . . . . . . . . & $\begin{array}{l}22.0-47.5 \pm 1.4 \\
47.5 \pm 1.4-52.0\end{array}$ & $\begin{array}{l}205 \pm 7 \\
590 \pm 42\end{array}$ \\
\hline Barnsdahl. ............. & $\begin{array}{l}22.0-40.4 \\
40.4 \pm 0.9-52.0\end{array} \pm 0.9$ & $\begin{array}{l}184 \pm 5 \\
243 \pm 15\end{array}$ \\
\hline Ceresin $\ldots \ldots \ldots \ldots \ldots$ & $\begin{array}{l}22.0-27.4 \pm 0.8 \\
27.4 \pm 0.8-34.7 \pm 0.6 \\
34.7 \pm 0.6-42.2 \pm 1.1 \\
42.4 \pm 1.1-50.0\end{array}$ & $\begin{array}{r}307 \pm 46 \\
849 \pm 72 \\
471 \pm 62 \\
1,434 \pm 137\end{array}$ \\
\hline Montan . . . . . . . . . . & $\begin{array}{l}42.4 \pm 1.0-41.5 \pm 3.0 \\
41.5 \pm 3.0-52.0\end{array}$ & $\begin{array}{l}1,404 \pm 137 \\
188 \pm 7 \\
294 \pm 25\end{array}$ \\
\hline \multicolumn{3}{|c|}{ Insect } \\
\hline Beeswax (yellow) ........ & $\begin{array}{l}22.0 \\
41.2 \pm 1.2-50.0\end{array}$ & $\begin{array}{r}344 \pm 31 \\
1,048 \pm 170\end{array}$ \\
\hline Beeswax (bleached) & $\begin{array}{l}22.0 \\
38.6 \pm 0.7-50.6\end{array} \pm 0.7$ & $\begin{array}{l}271 \pm 12 \\
606 \pm 27\end{array}$ \\
\hline \multicolumn{3}{|c|}{ Plant } \\
\hline Carnauba............. & $22.0 \quad-52.0$ & $156 \pm 10$ \\
\hline 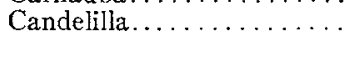 & $\begin{array}{l}22.0 \quad-40.2 \pm 1.4 \\
40.2 \pm 1.4-52.0\end{array}$ & $\begin{array}{r}182 \pm 9 \\
365 \pm 21\end{array}$ \\
\hline Ouricury ............. & $\begin{array}{l}22.0-43.0 \pm 2.8 \\
43.0 \pm 2.8-52.0\end{array}$ & $\begin{array}{l}186 \pm 14 \\
307 \pm 29\end{array}$ \\
\hline Japan wax.... & $\begin{array}{l}22.0-38.6 \pm 1.6 \\
38.6 \pm 1.6-45.0\end{array}$ & $\begin{array}{l}304 \pm 10 \\
755 \pm 170\end{array}$ \\
\hline \multicolumn{3}{|c|}{ Inlay } \\
\hline Kerr hard wax (blue)...... & $\begin{array}{l}22.0-37.5 \pm 0.5 \\
37.5 \pm 0.5-45.0 \pm 0.5 \\
45.0 \pm 0.5-50.0\end{array}$ & $\begin{array}{l}323 \pm 7 \\
629 \pm 22 \\
328 \pm 43\end{array}$ \\
\hline Kerr regular wax (blue).... & $\begin{array}{l}22.0-32.7 \pm 0.7 \\
32.7 \pm 0.7-40.9 \pm 1.0 \\
40.9 \pm 1.0-46.9 \pm 1.0 \\
46.9 \pm 1.0-50.0\end{array}$ & $\begin{array}{r}263 \pm 6 \\
662 \pm 42 \\
458 \pm 50 \\
1,084 \pm 144\end{array}$ \\
\hline
\end{tabular}

* Mean.

† Standard Deviation.

pansion of carnauba between $22^{\circ}$ and $52^{\circ} \mathrm{C}$. was linear. Paraffin possessed two linear rates and a very small amount of nonlinear expansion between $26^{\circ}$ and $28^{\circ} \mathrm{C}$. Yellow beeswax exhibited a gradually increasing rate of expansion, so that the rate of thermal expansion was non-linear throughout the temperature range of $22^{\circ}$ to $50^{\circ} \mathrm{C}$. Figure 5 also illustrates that Kerr's hard inlay wax had three linear rates of expansion with two very small non-linear expansion rates between 37.0 and $38.0^{\circ} \mathrm{C}$. and $44.5^{\circ}$ and $45.5^{\circ} \mathrm{C}$.

\section{Discussion}

The melting and setting ranges of waxes are valuable in identifying and classifying wax as well as in indicating the purity. The individual plant and mineral waxes possessed a wide variety of setting ranges between $41^{\circ}$ and $87^{\circ} \mathrm{C}$. Most of the waxes had a setting range of $2^{\circ} \mathrm{C}$., indicating that these materials are not entirely pure but are mixtures of compounds which solidify over a temperature range. Ceresin wax had the largest range--between $52^{\circ}$ and $73^{\circ} \mathrm{C}$.illustrating that it contains a wide range of 
molecular weights. The material appeared similar to a gel within the setting range in that the liquid wax was dispersed throughout the solid wax fibrils. The inlay waxes exhibited two setting ranges, indicating that these are combinations primarily of two major waxes.

The setting-range measurements illustrate that waxes are partially amorphous and partially crystalline, with the rate of

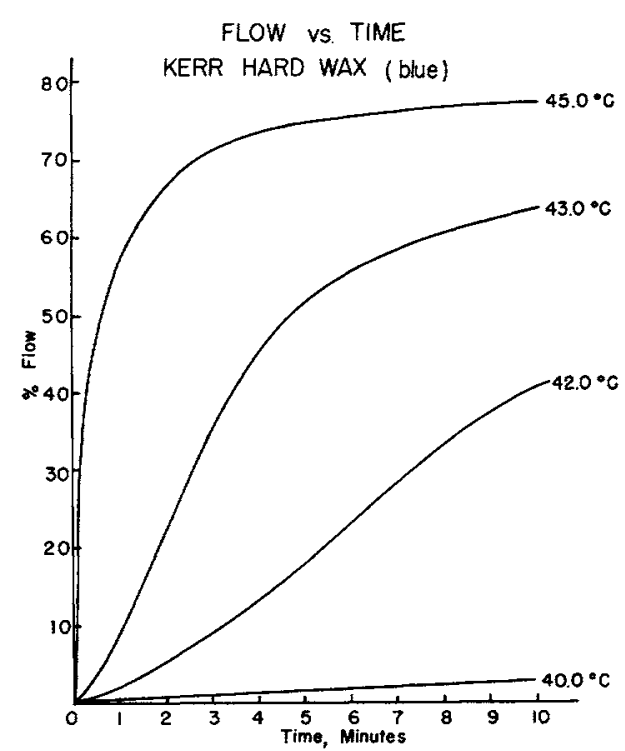

FIG. 4.-Flow curves at various times for Kerr hard wax.

temperature change during solidification indicating the degree of crystallinity. The differential plot shows this feature more dramatically, with the sharpness and extent of the peak indicating greater crystallinity. For example, paraffin wax was more crystalline than beeswax, which had a smaller and broader peak. The microcrystalline waxes likewise were less crystalline than paraffin wax, which would suggest their being used preferentially in dental waxes. Japan wax was the most crystalline, and the cooling curve showed supercooling, which is characteristic of highly crystalline materials.

Paraffin wax exhibited a second discontinuity in the cooling curve $10^{\circ}$ to $15^{\circ} \mathrm{C}$. below the solidification range $\left(37^{\circ}-42^{\circ} \mathrm{C}\right.$.) . This temperature is in agreement with the transition which has been described by
Bennet $t^{15}$ as the transformation from needleshaped crystals to rhomboid plates or leafy masses. These findings also are in agreement with those of Lasater, ${ }^{5}$ who has reported arrest points in dental waxes which he related to the distortion of wax patterns. This second-order transition point presents difficulties in that internal stresses result in wax patterns and it would be better if this point were well below room temperature. The use of microcrystalline waxes which have minute crystals and less orientation is preferred, and these should produce a more stable wax.

The importance of flow of wax at different temperatures has been emphasized by Taylor et $a l^{1,2}$ and Stanford et $a l .^{3}$ Yellow beeswax did not flow extensively until it

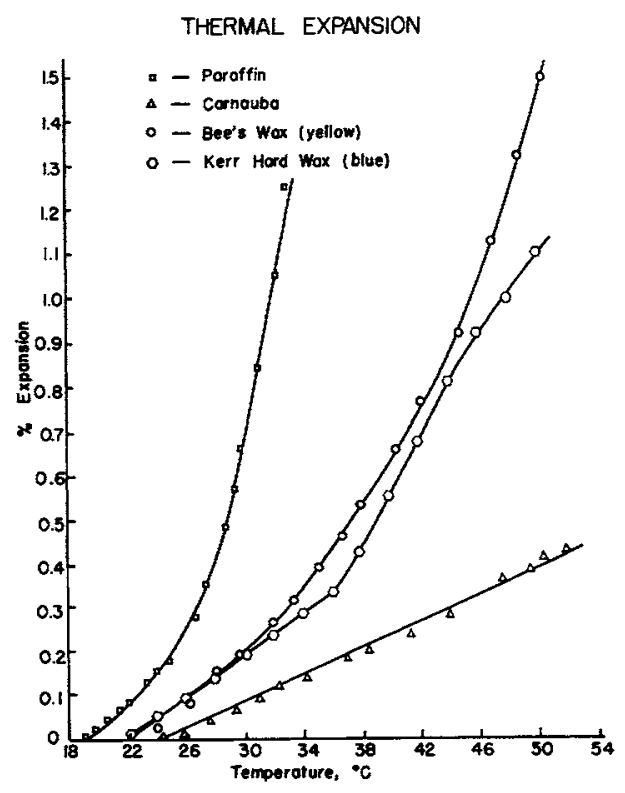

FIc. 5.-Thermal expansion curves for paraffin, carnauba, yellow bees, and Kerr hard waxes.

reached $38^{\circ} \mathrm{C}$., and at $40^{\circ} \mathrm{C}$. it flowed approximately 7 per cent. From these data it is easy to understand why beeswax has been used as a major ingredient in dental impression wax. Most of the mineral waxes had about a $10^{\circ} \mathrm{C}$. range between 1 and 70 per cent flow, which indicated that these waxes were softening gradually over a broad temperature range. Four of the five mineral waxes flowed 50 per cent approximately 
$20^{\circ} \mathrm{C}$. below their setting range. This might be explained by the fact that the mineral waxes are straight- or branch-chained hydrocarbons, and the secondary valence forces in these waxes are rather weak and gradually dissipated as the temperature is increased.

Montan wax was the only mineral wax which required a temperature as high as $71^{\circ} \mathrm{C}$, or $8^{\circ} \mathrm{C}$. below its setting point, in order to flow 50 per cent. This wax, however, is similar to the plant waxes in that it is composed mainly of esters formed in nature by the union of higher alcohols with the higher fatty acids. The plant waxes also required temperatures close to their setting ranges to produce 50 per cent flow. Due to the presence of esters groups in these waxes, the secondary valence forces are rather strong, and a high temperature is necessary to overcome these forces. Once the secondary valence forces are overcome, these waxes flow rapidly; below this point, however, they often appear to fracture in a manner similar to a brittle material.

Yellow beeswax, which is also primarily an ester wax, flowed extensively $24^{\circ} \mathrm{C}$. below its setting range and displayed an $8^{\circ} \mathrm{C}$. temperature difference between 1 and 70 per cent flow. This may be explained by the fact that yellow beeswax contains a large number of impurities which interfere with the secondary valence forces. As beeswax goes through the bleaching process and some of these impurities are removed, the secondary valence forces increase. The flow data illustrate this point, since bleached beeswax required a temperature closer to its setting range to produce a large amount of flow, and the temperature difference between 1 and 70 per cent flow was only $4^{\circ} \mathrm{C}$.

A plot of per cent flow versus time for the hard inlay wax showed that at $40^{\circ} \mathrm{C}$. the amount of flow in relation to time was linear. The total amount of flow after 10 minutes at this temperature was only 2 per cent, and the wax possessed enough internal strength to withstand the external stress application. At $42^{\circ} \mathrm{C}$., after the load had been applied for 3 minutes, the internal strength was finally overcome and the rate of flow increased until the surface area of the specimen increased enough to cause a sufficient reduction in the external stress. This takes place at approximately $7 \mathrm{~min}$ - utes, at which time the rate of flow decreases. At $43^{\circ}$ and $45^{\circ} \mathrm{C}$, there is not enough internal strength to withstand the external stress, so that the rate of flow is very large at the beginning of the test.

The linear thermal expansion properties of the waxes also may be explained on the basis of the strength of secondary valence forces and the transition points. The mineral waxes generally possessed higher coefficients of linear thermal expansion than did the plant waxes. Koch and Concetta ${ }^{14}$ have found similar results. The mineral waxes expand more because they have weak secondary valence forces which are overcome easily by the energy absorbed during a rise in temperature. This permits more movement of the wax components, thus allowing a greater amount of thermal expansion.

Plant waxes, on the other hand, have high secondary valence forces due to the presence of high concentrations of esters. Since the secondary valence forces restrict the movement of the wax components, small coefficients of thermal expansion are observed until the setting range of the wax is approached. Again this phenomenon is illustrated by beeswax, where yellow beeswax had much higher coefficients of linear thermal expansion than did bleached beeswax.

Most of the waxes exhibited at least two rates of expansion between $22^{\circ}$ and $52^{\circ} \mathrm{C}$. These changes in rate of expansion occurred at second-order transition points. At these points the internal structural parts became more free to move. For example, during this transition hydrocarbon chains of a mineral wax became free to rotate; consequently, after a wax has been heated through a transition point, it is more free to expand. Ceresin and the inlay waxes exhibited more than two changes in rate of expansion. This is probably due to the fact that the ingredient waxes are undergoing second-order transitions which do not coincide with one another.

\section{Summary}

The purpose of this investigation was to categorize the ingredient waxes used in dental waxes by means of physical tests. Five mineral, four plant, two insect, and two inlay waxes were included. Their melting range, setting range, as determined from a 
plot of temperature change versus time, flow properties, and linear thermal expansion between $22^{\circ}$ and $52^{\circ} \mathrm{C}$. were studied.

The melting range, measured by the closed-capillary-tube method, and the setting range of the waxes were in fair agreement. Most of the waxes investigated solidified in a range of $2^{\circ}$ to $3^{\circ} \mathrm{C}$. between temperatures of $41^{\circ}$ and $87^{\circ} \mathrm{C}$. Each of the two inlay waxes exhibited two setting ranges. The rate of temperature change during solidification was much greater for paraffin than for beeswax. Japan wax was the only wax investigated that exhibited supercooling during solidification.

The mineral, insect, and inlay waxes flowed extensively at approximately $20^{\circ} \mathrm{C}$. below their setting ranges. The mineral waxes required about a $10^{\circ} \mathrm{C}$. temperature rise between 1 and 70 per cent flow. The plant waxes did not flow until they reached a temperature of $5^{\circ} \mathrm{C}$. or less than their setting range. The temperature rise between 1 and 70 per cent flow for the plant waxes was $2.6^{\circ}$ to $8.0^{\circ} \mathrm{C}$.

The coefficients of linear thermal expansion were less for plant waxes than for mineral waxes. Carnauba possessed the smallest coefficient of linear thermal expansion$156 \pm 10 \times 10^{-6} /{ }^{\circ} \mathrm{C}$.- - of all the waxes and was the only wax which exhibited a linear expansion between $22^{\circ}$ and $52^{\circ} \mathrm{C}$. All the other waxes had at least two rates of expansion over this temperature range.

\section{Conclusions}

Waxes solidify over temperature ranges the extent of which indicates their purity. Plant, mineral, and insect waxes are available which solidify over ranges between $41^{\circ}$ and $87^{\circ} \mathrm{C}$.

A plot of temperature change versus time indicates that inlay waxes are combinations of two or more ingredient waxes. The rate of temperature change during solidification and the presence of discontinuities in the cooling curves below solidification indicate the extent of crystallinity present in a wax. The more crystalline the wax, the greater is the internal stress in a wax specimen when manipulated below these temperatures.

Waxes composed mainly of hydrocarbons soften at low temperatures and over large temperature ranges. Plant waxes, composed mainly of esters, require temperatures near their setting range to produce a large amount of flow. These effects can be explained on the basis of differences in the strength of the secondary valence forces.

Plant waxes have lower coefficients of thermal expansion than mineral waxes; this also can be explained on the basis of large secondary valence forces.

Classification of waxes by composition and physical properties is a sounder basis than classification by the source of the wax.

\section{References}

1. Taylor, N. O, and Paffenbarger, G. C. A Survey of Current Inlay Casting Technics, $J$. Amer. dent. Ass., 17:2058-81, 1930.

2. Taylor, N. O., Paffenbarger, G. C., and Sweeney, W. T. A Specification for Inlay Casting Wax, $J$. A mer. dent. Ass., 18:40-52, 1941 .

3. Stantord, J. W., Weigel, K., and Paffenbarger, G. C. Second Revision of American Dental Association Specification No. 4 for Dental Inlay Casting Wax, J. Amer. dent. Ass., 62:45-53, 1961.

4. Maves, T. V. Recent Experiments Demonstrating Wax Distortion on All Wax Patterns when Heat Is Applied, $J$. Amer. dent. Ass., 19:606-13, 1932.

5. Lasater, R. L. Control of Wax Distortion by Manipulation, $J$. Amer. dent. Ass., 27:518-24, 1940.

6. Phillips, R. W., and Biggs, D. H. Distortion of Wax Pattern as Influenced by Storage Temperature, and Temperature of Wax Manipulation, $J$. Amer. dent. Ass., 41:27-37, 1950 .

7. Mumpord, G., and Phillips, R. W. Dimensional Change in Wax Patterns during Setting of Gypsum Investment, $J$. dent. Res., 37:351-58, 1958.

8. Hollenback, G. M., and Rhoads, J. E. A Study of the Behavior of Pattern Wax. II, J. S. Calif. dent. Ass., 27:419-34, 1959 .

9. 1. Thermal Expansion of Pattern Wax. III, ibid., 28:6-13, 1960 .

10. VAN AKEN, J. Distortion of Wax Patterns as Influenced by Setting and Hygroscopic Expansion of the Investment, T. Tandkeelk., 68:583-610, 1961.

11. Ellis, W. J. The Melting-Point Curves of Some Binary Wax Mixtures, $f$. Council sci. ind. Res. (Aust.), 16:179-84, 1943.

12. Koch, J. R., Hable, G. J., and Wrangeli, L. Melting-Point Studies of Binary and Trinary Mixtures of Commercial Waxes, Ind. Eng. Chem., Anal. Ed., 10:167-68, 1938.

13. EllIS, W. J. Melting Points. II. Melting Points of Binary Wax Mixtures, Petroleum (Lond.), 8:115, 1945.

14. KoCr, J. R., and Concetta, Sister M. The Effect of Composition on the Specific Gravity of Binary Wax Mixtures, Trans. Kentucky Acad. Sci., 13:104-10, 1950.

15. BenNetr, H. Industrial Waxes, Vols. I and 2. New York: The Chemical Publishing Company, Inc., 1963.

16. WARTH, A. H. The Chemisiry and Technology of Waxes, chaps. 2-5. 2d ed. New York: Reinhold Publishing Corp., 1956.

17. Guide to Dental Materials, pp. 95-98. 2d ed. Chicago: American Dental Association, 1964. 